\title{
POTENSI SITU JABODETABEK SEBAGAI WADUK RESAPAN
}

\author{
Teddy W Sudinda \\ Pusat Teknologi Lingkungan, BPPT, Kawasan Puspiptek, Tangerang Selatan, 15314, Indonesia \\ E-mail: teddy.sudinda@gmail.com
}

\begin{abstract}
ABSTRAK
Keberadaan situ-situ di wilayah Jabodetabek sampai saat ini dapat dikatakan terlantar dalam penanganannya sehingga telah terjadi perubahan fungsi. Dengan semakin besarnya konsentrasi penduduk di wilayah Jabotabek maka beban terhadap sumberdaya air di wilayah tersebut semakin besar. Keadaan di atas merupakan ancaman bagi konservasi sumber daya air. Upaya pelestarian situ dalam rangka perlindungan dan konservasi sumberdaya alam, khususnya sumberdaya air, dan ekosistem secara keseluruhan perlu dilakukan secara terpadu oleh semua pihak yang terkait dan berkepentingan dan melibatkan berbagai disiplin ilmu. Untuk mengetahui potensi situ yang memungkinkan fungsinya sebagai waduk resapan perlu didahului dengan inventarisasi mencakup aspek teknis dan IPTEK.
\end{abstract}

Kata kunci: waduk resapan (WR), konservasi, aquifer

\section{POTENTIAL OF SITU JABODETABEK AS A INFILTRATION LAKE}

\section{Teddy W Sudinda}

Center for Environmental Technology, BPPT, Puspiptek Area, South Tangerang, 15314, Indonesia E-mail: teddy.sudinda@gmail.com

\begin{abstract}
The existence of a lake in the Jabodetabek area can be said to be neglected in its handling so that there has been a change in function. With the increasing concentration of the population in the Jabotabek region, the burden on water resources in the region is even greater. The above situation is a threat to the conservation of water resources. Situ conservation efforts in the context of protection and conservation of natural resources, especially water resources, and the ecosystem as a whole need to be carried out in an integrated manner by all parties concerned and interested and involving various disciplines. To find out the potential of the site which allows its function as a recharge reservoir, it needs to be preceded by an inventory covering technical aspects and science and technology.
\end{abstract}

Keywords: Infiltration Lake, Conservation, Aquifer 


\section{LATAR BELAKANG}

Pada tahun 2025 diperkirakan jumlah penduduk di Jabotabek akan mencapai 39 juta jiwa dimana 13 juta jiwa akan menempati DKI Jakarta, 10 juta jiwa di Kabupaten Bogor, 9,2 juta jiwa di Kabupaten Tangerang dan 6,8 juta jiwa di Kabupaten Bekasi (Studi JWRM, 1994). Dengan semakin besarnya konsentrasi penduduk di wilayah Jabotabek tersebut, maka beban terhadap sumberdaya air di wilayah tersebut semakin besar. Keadaan di atas merupakan ancaman bagi konservasi sumber daya air. Bila hal ini dibiarkan tanpa adanya upaya pengelolaan sumber daya air yang berkelanjutan boleh jadi akan terjadi defisit sumber daya air di tahun-tahun mendatang.

Keberadaan situ sangat penting dalam turut menciptakan keseimbangan ekologi dan tata air. Dari sudut ekologi, situ merupakan ekosistem yang terdiri dari unsur air, kehidupan akuatik, dan daratan yang dipengaruhi tinggi rendahnya muka air, sehingga kehadiran situ akan mempengaruhi iklim mikro dan keseimbangan ekosistem di sekitarnya. Sedangkan ditinjau dari sudut tata air situ-situ berperan sebagai reservoir yang dapat dimanfaatkan airnya untuk keperluan sistem irigasi dan perikanan, sebagai sumber air baku, sebagai tangkapan air untuk pengendali banjir, suplai air tanah dan pariwisata.

Luas situ di wilayah Jabodetabek sekarang ini adalah 1.462,78 hektar, dengan kedalaman yang hanya dua meter, situ-situ hanya mampu menampung sekitar 29,26 juta meter kubik. Padahal, bila dilakukan pengerukan dan pendalaman secara teratur hingga mencapai kedalaman ideal lima meter, volume air yang mampu tertampung mencapai tiga kali lipatnya, atau sebanyak 73,14 juta meter kubik. Itu baru pendalaman yang dilakukan terhadap situ-situ yang masih sisa di wilayah Jabodetabek saja. Bila pemerintah sanggup mengembalikan luas situ seperti semula (2.337,10 hektar), volume air yang bisa ditampung mencapai 116,86 juta meter kubik.

Keberadaan situ-situ di wilayah Jabodetabek sampai saat ini dapat dikatakan terlantar dalam penanganannya sehingga telah terjadi perubahan fungsi, hilang atau bahkan diperjualbelikan. Di satu sisi, keterlambatan dalam pananganan situ-situ di wilayah ini pada akhirnya dapat memberikan dampak berupa beban sosial dan lingkungan pada masyarakat di sekitarnya. Padahal, di sisi lain, dengan penerapan pola pengelolaan situ-situ secara optimal dengan sistem manajemen yang baik akan memberikan nilai ekonomis dan dapat meningkatkan taraf hidup masyarakat serta dapat mempertahankan kelestarian lingkungan yang berkelanjutan.
Situ-situ di wilayah Jabodetabek mempunyai peranan penting dalam konservasi sumberdaya alam khususnya sumberdaya air dan ekosistem secara keseluruhan. Sedangkan fungsinya adalah sebagai sumber air bagi kehidupan masyarakat, pengaturan tata air dan pemasok air tanah, pengendali banjir, pengatur iklim mikro, habitat flora dan fauna, mencegah instrusi air laut, pengendap lumpur dan pengikat zat pencemar, rekreasi dan budidaya perikanan.

Akibat dari peningkatan jumlah penduduk dan aktivitas pembangunan situ-situ banyak berubah menjadi kawasan permukiman, mengalami pengurangan luas, tempat pembuangan limbah dan sebagainya, sehingga situ tersebut kehilangan fungsinya. Ancaman terhadap keberadaan dan kelestarian situ umumnya disebabkan oleh adanya konversi lahan, pendangkalan, dan pencemaran oleh limbah.

Upaya pelestarian situ dalam rangka perlindungan dan konservasi sumberdaya alam, khususnya sumberdaya air, dan ekosistem secara keseluruhan perlu dilakukan secara terpadu oleh semua pihak yang terkait dan berkepentingan dan melibatkan berbagai disiplin ilmu. Untuk mengetahui potensi situ yang memungkinkan fungsinya sebagai waduk resapan dan perlu didahului dengan inventarisasi mencakup aspek teknis dan IPTEK.

\section{PERSYARATAN WADUK RESAPAN}

\section{PEMBANGUNAN}

2.1. Rencana lokasi, luas dan pemilikan lahan Rencana lokasi WR dipilih dari situ-situ yang mempunyai penyebaran yang merata dibagian hulu perbatasan selatan DKI Jakarta, mempunyai luas sedikitnya 3 hektar (ha). Kepemilikan situ harus jelas milik negara (Pemda / Pusat) dengan batas-batas yang ditunjukkan didalam surat tanah atau sertifikat situ. Pemilikan negara dan batas-batas situ penting untuk menghindari tuntutan dari anggota masyarakat setempat (individu / kelompok) yang merasa memiliki / sewa atau jangan menimbulkan ganti rugi. Lokasi WR selain penyebaran yang merata juga dilihat dari rencana sumber air untuk diresapkan. Sebagai alternatif adanya jaminan sumber air adalah adanya anak sungai atau sungai yang terdapat dekat lokasi situ. Penyebaran rencana lokasi WR yang dimaksud, karena ditujukan untuk perlindungan wilayah DKI Jakarta, maka penyebaran pada perbatasan hulu DKI Jakarta dari Barat ke Timur secara berlapis kearah selatan pada wilayah Kota Depok, Kabupaten Bogor, Kota / Kabupaten Bekasi dan Kabupaten Tangerang. 


\subsection{Geologi Teknik}

Waduk Resapan dengan memanfaatkan situ, secara geologi teknik sudah terpenuhi. Lapisan tanah pada dasar situ umumnya permeable karena mata air didasar atau pada lereng situ, air bisa keluar dengan cukup deras. Jadi persyaratan koefisien permeabilitas (k) sudah melebihi nilai $5 \cdot 10^{-4} \mathrm{~m} / \mathrm{dt}$. Persyaratan daya dukung tanah, lapisan tanah dibawah atau sekitar situ terbentuk dari proses pengangkatan batuan sekelilingnya atau terjadi amblasan dari bagian dasar situ; sehingga lapisan tanah sudah terkonsolidasi lama dan menjadi kuat. Tanah mempunyai daya dukung tinggi $\left(\sigma_{t}>2 \mathrm{~kg} / \mathrm{m}^{2}\right.$ ), sebagai pondasi bangunan air seperti pintu air, pelimpah (spillway), dinding pasangan batu, tanggul penutup, serta sarana lain seperti jalan, parkir dan bangunan fasilitas umum (kantor,kios/ toko, WC, masjid dan lain-lain). Persyaratan geologi lain adalah dibawah WR harus ada aquifer atau lapisan pasir yang menerus skala regional baik aquifer dangkal, semi tertekan bahkan aquifer tertekan. Karena situ berada di cekungan, maka bisa jadi lereng situ sudah memotong lapisan-lapisan aquifer dangkal atau semi tertekan, sehingga untuk mendapatkan koneksitas lapisan aquifer tersebut tidak perlu menggali dalam-dalam, mungkin sekitar $2-4 \mathrm{~m}$ sudah bertemu aquifer yang dapat membawa debit resapan dari WR lebih besar dan meluas. Persyaratan geologi teknik lain seperti adanya sesar aktif (fault) atau dekat sumber gempa tektonik maupun vulkanik, sudah terpenuhi secara alamiah karena situ-situ sudah ada (exist), sejak proses geologi, sehingga tidak mengkhawatirkan jika situ ditingkatkan menjadi waduk resapan. Akan tetapi jika ada jalur / garis sesar, dapat diupayakan garis atau sumbu memanjang bangunan seperti tubuh bendungan / tanggul penutup dibuat sejajar dengan jalur sesar. Jalur-jalur sesar dapat diidentifikasi dari peta geologi regional dan juga tanda-tanda (trust) dilapangan.

\subsection{Sumber Air dan Prasarana Bangunan Air}

Sumber air situ sebenarnya mata air / air tanah yang keluar dari dasar dan tebing / lereng situ. Akan tetapi jika ditingkatkan menjadi waduk resapan, maka sumber air harus dari luar atau air permukaan seperti debit anak-anak sungai atau debit sungai utama yang berpotensi membawa debit banjir. Untuk WR disekitar wilayah DKI Jakarta, sumber air dari anak-anak Sungai Ciliwung dan Sungai Ciliwung sendiri dan sungai kecil lainnya yang masuk ke wilayah DKI Jakarta, seperti sungai Krukut, Buaran, Angke dan lainlain. Kualitas sumber air harus bersih, tidak banyak membawa sedimen; Konsentrasi sedimen didalam debit diharapkan kurang dari $1000 \mathrm{ppm}$ (=1 gram solid $/ \mathrm{m}^{3}$ air) dan tidak mengandung logam berat, $\mathrm{Hg}, \mathrm{Ag}$ dan $\mathrm{Fe}$. Jika sedimen terlalu banyak, atau air sangat keruh, maka air perlu dijernihkan dulu, lewat kolam pengendapan atau saluran kantong lumpur sebelum masuk ke WR. Prasarana bangunan air atau fasilitas yang harus ada adalah bendung, intake / pintu pemasukan air dan pintu pengeluaran air (outlet) serta pelimpah. Bendung berfungsi menaikkan muka air di kali / sungai agar bisa masuk ke WR, bendung dilengkapi pintu penguras sedimen yang berada didepan intake. Air yang masuk ke WR diatur dan diukur oleh pintu sorong dan ambang lebar pada intake. Air yang lebih dibuang lewat pelimpah (spillway) bendung. Intake / pintu pengambilan dapat dioperasikan buka / tutup untuk mengatur dan mengukur debit masuk.

\section{PEMANFAATAN SITU UNTUK WADUK RESAPAN}

\subsection{Kondisi Sumber Air}

Sumber air situ umumnya berupa mata air dari air tanah yang terpotong oleh lereng-lereng situ. Karena letak situ paling rendah terhadap lahan sekitarnya, sehingga air tanah dan air hujan menuju dan mengisi situ. Situ-situ yang dekat sumber air permukaan misalnya dari anak-anak sungai mempunyai potensi yang baik untuk dikembangkan menjadi waduk resapan. Karena waduk resapan bekerja secara aktif dan terus menerus, harus ada sumber air yang permanen, satu-satunya cara dengan membelokkan aliran anak-anak sungai atau sungai ke waduk resapan. Pembelokkan debit sungai ini juga akan mengurangi beban debit anak-anak sungai atau sungai.

\subsection{Kondisi dan Luas Tangkapan Air Situ}

Luas daerah tangkapan situ tergantung dari terdapat tidaknya anak sungai yang masuk ke waduk resapan. Jika banyak sungai yang masuk ke situ, luas daerah tangkapan situ jauh lebih luas. Semakin luas daerah tangkapan situ semakin potensial dijadikan waduk resapan, dan tentunya semakin efektif sebagai pengendali banjir.

\subsection{Kondisi Tutupan Lahan Tangkapan Situ}

Tutupan lahan daerah tangkapan situ di DAS Ciliwung - Cisadane, umumnya sudah terbuka, dimana dimanfaatkan budidaya pertanian tegalan/palawija dan sawah/padi, serta untuk permukiman dan fasilitasnya. Kondisi lahan demikian mempunyai koefisien limpasan (run off coeficient) C berkisar $0,60-0,65$, sehingga hanya $35-40 \%$ dari air hujan, menguap kembali dan infiltrasi ke dalam tanah. Jumlah air hujan yang mengisi aliran tanah kurang $20 \%$ nya dan karena luas daerah tangkapan pendek, maka infiltrasi hanya mengisi pada akuifer dangkal. 


\subsection{Kondisi Topografi dan lereng Situ}

Topografi situ dan daerah tangkapan umumnya menurun ke pusat situ, dengan kemiringan sedang sampai curam sesuai dengan batuan dan topografi disekitarnya seperti pegunungan, perbukitan atau dataran. Lereng yang terbentuk sudah stabil sesuai proses geologi dan kemiringan bebas dari material lapukan batuan. Kemiringan bebas yang terbentuk secara alami oleh material tanah sudah mempunyai kekuatan lereng situ yang cukup tinggi, apalagi permukaan lereng ditumbuhi rumput yang menambah kestabilan lereng. Apabila situ dibuat waduk resapan, kemiringan dinding galian dibuat tegak agar luas permukaan maksimal (luas dasar dan permukaan sama). Apapun jenis tanahnya dinding galian harus diperkuat dengan struktur seperti tembok beton/pasangan batu (retaining wall), turap (sheet pile), geotekstil, jaring-jaring dan lain-lain.

\subsection{Kondisi Kedalaman Situ}

Kedalaman perairan situ hampir semua fluktuatif, apalagi pemanfaatan akhir-akhir ini banyak mengurangi jumlah air, seperti untuk irigasi. Disamping itu situ mengalami pendangkalan dan tidak pernah dikeruk, selain tidak ada program/dana, juga sulit cara untuk membuang endapan atau sulit mencari deposit area. Endapan yang tertumpuk dari tahun ke tahun mengeras, apalagi pernah kering, sehingga situ menjadi rata dan ditumbuhi rumput/eceng gondok dan membuat perairan situ dangkal. Kedalaman alami rata-rata 0,5-2,0 m. Untuk menjadi waduk resapan, endapan tersebut digali 4-8 $\mathrm{m}$, dengan dipastikan dapat bertemu lapisan pasir yang porous, sehingga air dapat meresap banyak dan mengalir luas di dalam akuifer dangkal, semi maupun akuifer dalam.

\subsection{Kondisi Hidrologi dan Hidrogeologi}

Situ-situ yang berada didalam DAS Ciliwung Cisadane berada dalam wilayah Jawa Barat yang relatif lebih banyak hujan disbanding wilayah lain. Apalagi hulu DAS Ciliwung berada di Kabupaten Bogor/Cianjur, yang mempunyai hujan rata-rata tahunan lebih dari $3000 \mathrm{~mm}$, sehingga secara hidrologis merupakan daerah basah (wetted land). Dengan demikian sumber air untuk waduk resapan dari hujan maupun debit sungai tidak akan kurang. Akan tetapi tata guna DAS Ciliwung - Cisadane harus diperbaiki, dengan ruang terbuka hijau dan hutan yang dapat berfungsi mengawetkan air hujan, mencapai rata-rata $50 \%$ atau dibagian hulu DAS hutannya lebih $60 \%$ dan dibagian hilir ruang terbuka hijau lebih $40 \%$ nya sesuai dengan rencana tata ruang Propinsi Jawa Barat dan Kota/Kabupaten bogor dan Cianjur. Waduk resapan sebagai resapan air akan lebih baik jika dibuat pada situ-situ yang letaknya berada dibagian tengah ke hulu dari DAS Ciliwung. Semakin hulu waduk resapan dibuat maka semakin pendek (dangkal) galian yang diperlukan dasar waduk resapan, dan aliran air tanah dari resapan air dapat mudah masuk ke akuifer dalam/tertekan setelah sampai di kawasan DKI Jakarta.

\subsection{Kondisi Kualitas Air}

Kualitas air situ secara variabel yang dapat diukur adalah keasaman / kesadahan $(\mathrm{pH})$, kejernihan/kekeruhan, dan ganggang/lumut. Keasaman atau kesadahan air tergantung dari peruntukan situ. Untuk pemanfaat perikanan, sisa makanan yang merupakan bahan organik membuat air menjadi asam $(\mathrm{pH}<7)$, dan ganggang dan lumut mudah hidup, sehingga warna air menjadi hijau. Jika situ dipakai banyak untuk mandi ditempat dan mencuci pakaian, busa sabun / ditergen, membuat air menjadi basa (sadah) atau $\mathrm{pH}>7$. Kandungan logam berat seperti $\mathrm{Hg}, \mathrm{Ag}$ dan Fe perlu diwaspadai karena di DAS Ciliwung banyak pusat industri sedang dan berat. Kualitas air seperti $\mathrm{pH}$ rendah / tinggi mampu juga dinetralkan oleh material tanah setelah air meresap dan mengalir secara phisik disaring (filtering), secara biologi dimakan bakteri mikroba tanah dan secara hidrolik : pengenceran (flushing). Jarak aliran air tanah yang panjang memberikan perbaikan kualitas secara efektif. Jadi waduk resapan yang dibuat dihulu jauh (puluhan $\mathrm{km}$ ) dari DKI Jakarta, air tanah resapan waduk resapan dipastikan berkualitas air minum.

\subsection{Kondisi Peruntukan Situ}

Situ-situ saat ini dimanfaatkan banyak kebutuhan jenis air seperti : kebutuhan sehari-hari penduduk sekitar, perikanan keramba, suplesi irigasi sawah/kolam ikan, ladang/sawah dilahan situ. Belum ada / tidak ada pengaturan peruntukan. Situ-situ yang dijadikan waduk resapan, dipilih yang peruntukan sekarang masih asli, hanya sebagai sumber air bersih bagi masyarakat sekitar. Jika sudah ada pemanfaatan irigasi dan lainnya secara cukup lama (senior user), maka harus ada konsultansi dengan stekholder bahwa apakah perubahan situ ke waduk resapan dapat diterima. Kebutuhan air masih diupayakan bisa dengan batas kemampuan suplesi, namun ikut memelihara dengan partisipasi aktif. Dengan situ berubah waduk resapan, ada tambahan fungsi baru, menampung dan meresapkan, disamping fungsi / peruntukan situ terdahulu.

\subsection{Sebaran dan Luas potensi Situ Untuk Waduk Resapan}

Lokasi situ di DAS Ciliwung - Cisadane dengan jumlah lebih 300 situ tersebar sepanjang bantaran sungai Ciliwung, yang topografinya relatif rendah, dengan luas lebih dari 300 ha, 
seperti diberikan pada gambar terlampir. Dari segi sebaran, lokasi situ mempunyai konfigurasi yang memanjang dari selatan ke utara searah dengan alur sungai Ciliwung. Akan tetapi karena alur sungai membentuk meander (berkelokkelok), maka posisi situ-situ tersebar melebar dari timur ke barat melewati lebar batas kawasan DKI Jakarta.

Situ-situ yang berada di DAS Ciliwung dianalisis untuk bisa dijadikan atau berpotensi untuk waduk resapan. Dasar analisis adalah indikator phisik dan non phisik yang memenuhi minimum standar atau syarat Waduk Resapan, yang telah ditetapkan secara umum terdahulu. Berdasarkan syarat-syarat waduk resapan seperti yang telah diuraikan diatas, jumlah situ dan luas potensi untuk waduk resapan adalah (data situ Jabodetabek).

- Wilayah DKI Jakarta : 16 situ, luas \pm 117 ha (luas situ $\geq 2$ ha)

- Wilayah Depok, Bogor : 122 situ, luas \pm 1000 ha

Dengan demikian jumlah total situ potensi waduk resapan adalah 138 lokasi dengan luas \pm 1117 ha. Kapasitas potensi waduk resapan tersebut dengan rata-rata kedalaman $5,0 \mathrm{~m}$, adalah \pm 60 juta meter kubik atau setara $10 \%$ volume waduk yang diperlukan pengendali banjir sungai Ciliwung ( \pm 600 juta meter kubik).

\subsection{Kelompok Hidrologi Tanah (Soil Hidrology Group)}

Untuk menghitung karakteristik infiltrasi tanah U.S. Soil Conservation Service membagi tanah ke dalam empat Soil Hidrological Group, yang didefinisikan sebagai berikut:

a. Grup A: potensi run-off rendah, tanah mempunyai laju transmisi air tinggi (laju infiltrasi final lebih besar $0,72 \mathrm{~cm} / \mathrm{jam})$, tektur berpasir.

b. Grup B: tanah mempunyai laju transmisi air tergolong sedang (laju infiltrasi final antara $0,72-0.36 \mathrm{~cm} / \mathrm{jam})$, tektur lempung berpasir.

c. Grup C: tanah mempunyai laju transmisi air tergolong lambat (laju infiltrasi final antara 0,36-0,12 cm/jam), lempung berliat, lempung berpasir dangkal, tanah berkadar bahan organik rendah, dan tanah -tanah berkadar liat tinggi.

d. Grup D: potensi run-off tinggi, tanah mempunyai laju transmisi air tergolong sangat rendah (laju infiltrasi final lebih kecil 0,12 cm/jam), tanah-tanah yang mengembang secara nyata jika basah, liat berat, dan plastis.

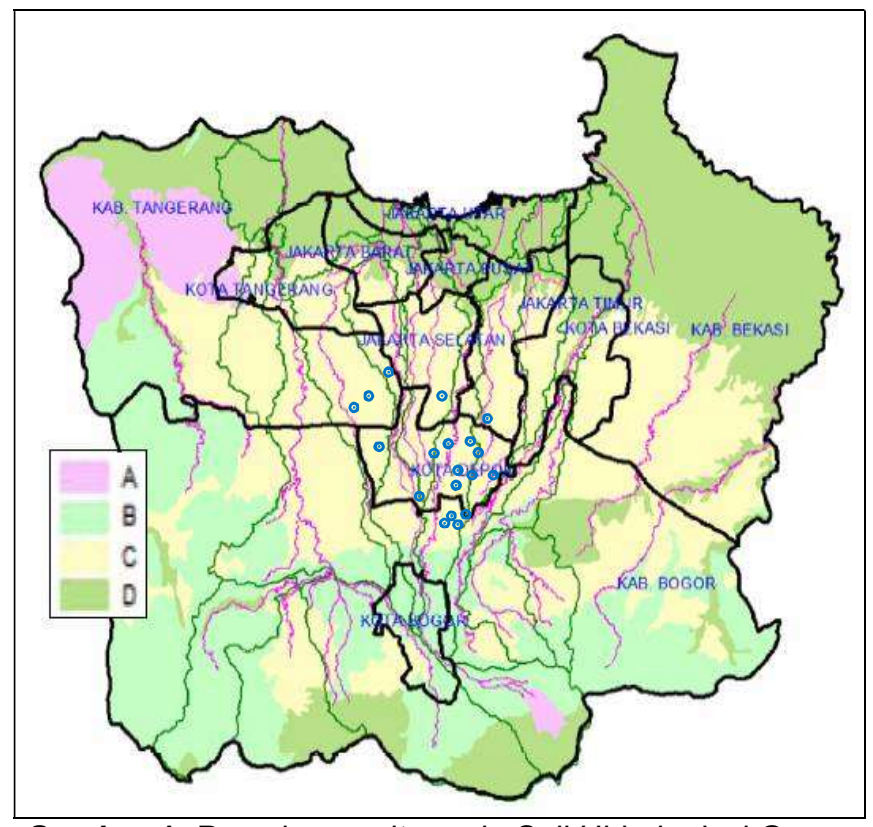

Gambar 1: Persebaran situ pada Soil Hidrological Group

Berdasarkan persebaran 13 situ pada Soil Hidrological Group, maka seluruh situ berada pada Grup C yaitu tanah mempunyai laju transmisi air tergolong lambat (laju infiltrasi final antara 0,36-0,12 cm/jam), lempung berliat, lempung berpasir dangkal, tanah berkadar bahan organik rendah, dan tanah berkadar liat tinggi lihat Gambar 1.

\section{KELAYAKAN SITU SEBAGAI WADUK RESAPAN}


Berdasarkan deskripsi masing-masing situ tersebut di atas, maka terdapat 25 situ dengan luas total 244,23 ha yang layak dikembangkan untuk waduk resapan (Tabel1). Jumlah luas total situ tersebut tidak termasuk situ-situ Rektorat UI, Ekonomi UI, Politeknik UI, Salam UI, Asrama UI, Gintung, Pondok Benda, Rawa Dongkal yang belum terhitung luasnya. Dari 25 situ tersebut hanya 10 situ yang berada di dalam DAS Ciliwung, 2 situ di DAS Pesanggrahan, 4 situ di DAS Angke, dan 1 situ di DAS Cipinang. Dengan kata lain terdapat sekitar 19 situ yang berada di dalam sistem sungai di daerah Jakarta yang berhubungan langsung dengan sistem banjir di DKI Jakarta.

Tabel 1: Hasil pengamatan situ yang layak sebagai waduk resapan di Jabodetabek

\begin{tabular}{|c|l|l|l|}
\hline No & \multicolumn{1}{|c|}{ Situ } & \multicolumn{1}{c|}{ Luas } & Sistem Sungai \\
\hline 1 & Bekang/Gedong & 6,79 ha & Ciliwung \\
\hline 2 & Cikaret & 29,5 ha & Ciliwung \\
\hline 3 & Cilangkap & 6 ha & Ciliwung \\
\hline 4 & Cilodong & 9,5 ha & Ciliwung \\
\hline 5 & Citatah/Ciriung & 9,25 ha & Ciliwung \\
\hline 6 & Rektorat UI & - & Ciliwung \\
\hline 7 & Ekonomi UI & - & Ciliwung \\
\hline 8 & Politeknik UI & - & Ciliwung \\
\hline 9 & Salam UI & - & Ciliwung \\
\hline 10 & Asrama UI & - & Ciliwung \\
\hline 11 & Rawa Baru & 7,5 ha & Ciliwung \\
\hline 12 & RRI & 7,2 ha & Ciliwung \\
\hline 13 & Bojongsari/Sawangan & 28,25 ha & Pesanggrahan \\
\hline 14 & Gintung & - & Pesanggrahan \\
\hline 15 & Kemuning & 12,65 ha & Angke \\
\hline 16 & Pamulang/Kedaung/Sasak & 25 ha & Angke \\
\hline 17 & Pondok Benda/Kompeni/Ciledug & - & Angke \\
\hline 18 & Tonjong & 14,44 ha & Angke \\
\hline 19 & Rawa Dongkal & - & Cipinang \\
\hline 20 & Cigago/Kemang & 29,4 ha & Cisadane \\
\hline 21 & Cilala/Jampang & 18 ha & Cisadane \\
\hline 22 & Iwul & 9,75 & Cisadane \\
\hline 23 & Lebak Wangi & 5,5 ha & Cisadane \\
\hline 24 & Malang Nengah & 18,5 ha & Cikeas \\
\hline 25 & Gunung Putri & & \\
\hline & & & \\
\hline
\end{tabular}




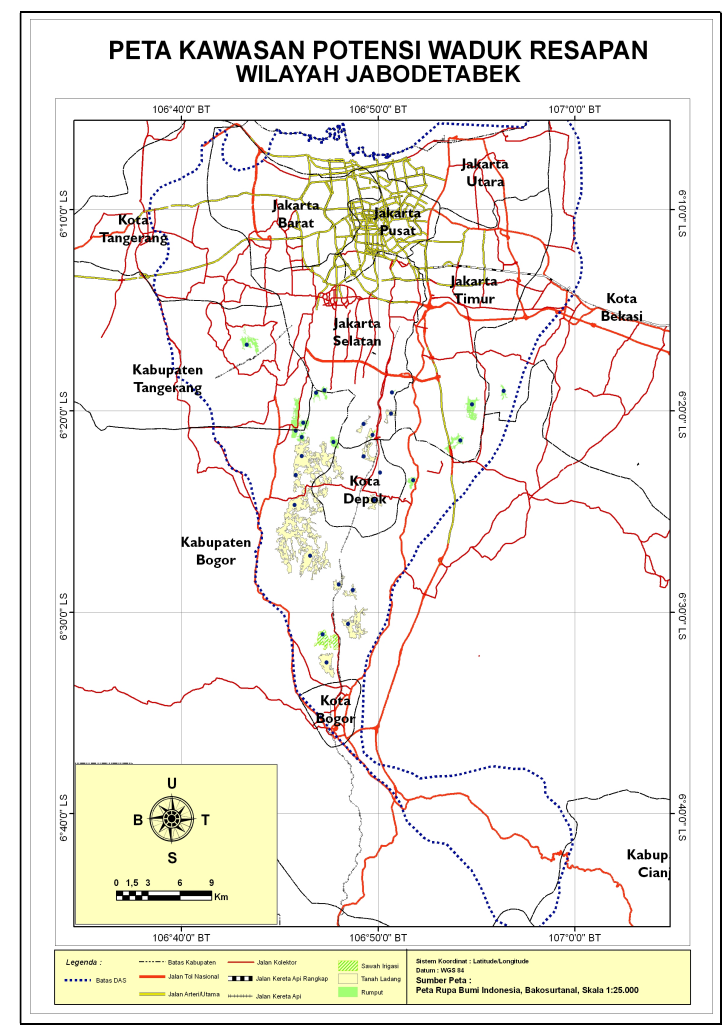

Gambar 2: Penyebaran situ-situ yang berada di Jabodetabek

Peta kawasan potensi waduk resapan serta penyebarannya situ-situ di wilayah jabodetabek dapat dilihat pada Gambar 2 dan Gambar 3.

Kelayakan dari 19 situ untuk pengembangan waduk resapan tersebut adalah kelayakan teknis (fisik) belum mempertimbangkan aspek sosial, ekonomi dan budaya serta financial secara menyeluruh. Beberapa pertimbangan yang berkaitan dengan aspek sosial seperti kepadatan penduduk di sekitar situ dan pemanfaatan situ oleh penduduk sekitarnya, sudah menjadikan pertimbangan dalam menentukan kelayakan situ. Namun demikian analisisnya belum dilakukan secara mendalam karena kendala waktu dan sesuai batasan operasional dalam studi.

Aspek teknis dalam menentukan kelayakan situ yang berpotensi untuk dimanfaatkan atau dikembangkan sebagai waduk resapan dengan melihat kondisi akifer yang berada dibawah waduk sebaiknya mempunyai nilai permeabilitas yang porous sehingga air dengan mudah meresap ke lapisan akifer dan waduk resapan mempunyai sumber air yang sepanjang tahun air memenuhi waduk dengan elevasi air yang ditentukan, 


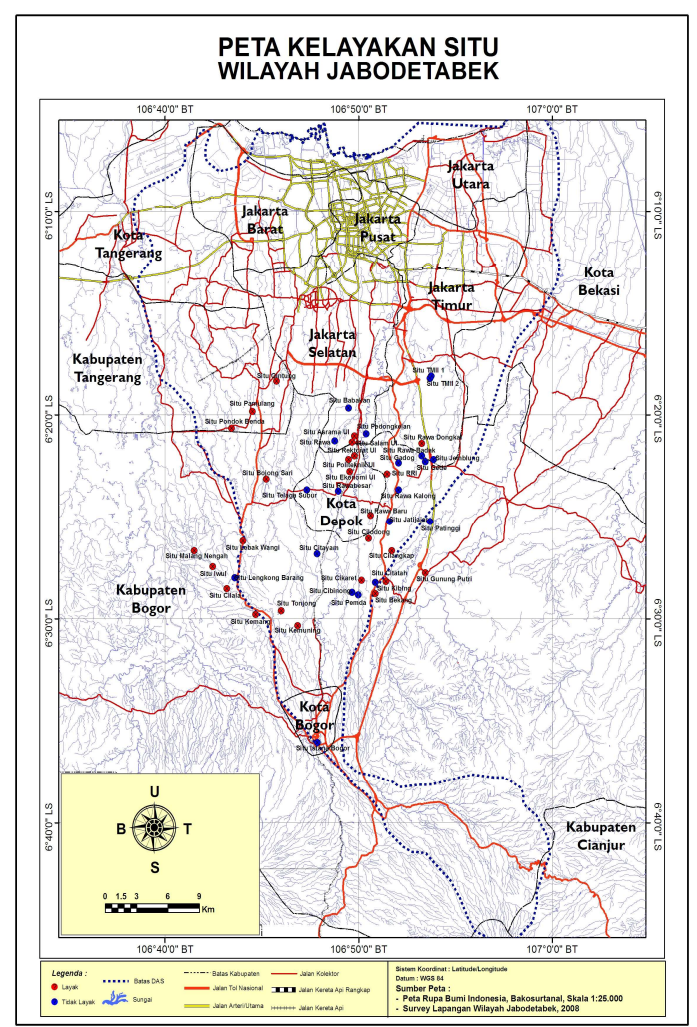

Gambar 3: Potensi situ-situ di Jabodetabek

\section{PENGEMBANGAN LAHAN SEBAGAI WADUK RESAPAN}

Berdasarkan analisis spasial, maka beberapa lokasi dapat diidentifikasikan sebagai lahan yang layak untuk pengembangan waduk resapan. Kriteria yang digunakan dalam analisis spasial tersebut berdasarkan analisis terhadap landscape catchment area dengan mempertimbangkan penggunaan lahan (landuse), lereng dan sistem sungai. Metode yang digunakan dalam studi ini lebih lengkap dibandingkan dengan metode yang dilakukan oleh Masyarakat Air Indonesia/MAI (2003). Metode yang dilakukan MAI untuk identifikasi lahan-lahan potensial pengembangan waduk resapan di daerah DKI Jakarta, dengan mempertimbangkan eksistensi lahan tersebut adalah tanah kosong (tidak berpenghuni) atau bukan yang berada di sekitar sungai. Asumsi yang digunakan adalah ketika terjadi banjir maka debit sungai dimasukkan ke dalam akuifer melalui waduk resapan.

Lokasi-lokasi hasil identifikasi merupakan lahan tegalan, ladang, padang rumput atau tanah kosong yang keberadaaannya di sekitar sungaisungai besar yaitu di sekitar sungai Ciliwung, Pesanggrahan, Angke, Cipinang dan Sunter hulu. Total luas lahan yang layak untuk pengembangan waduk resapan adalah 27 lokasi dengan luas 1122.35 ha lihat Tabel 2. Peta sebaran potensi waduk resapan wilayah Jabodetabek yang layak dimanfaatkan / dikembangkan sebagai waduk resapan dijelaskan pada Gambar 4.

Tabel 2. Potensi Lahan untuk Waduk Resapan

\begin{tabular}{|l|l|c|c|l|l|}
\hline No & \multicolumn{1}{|c|}{ Land Use } & $\begin{array}{c}\text { Luas Land Use } \\
(\mathbf{H a})\end{array}$ & $\begin{array}{c}\text { Luas Potensi Situ } \\
(\mathbf{H a})\end{array}$ & Kecamatan & \multicolumn{1}{|c|}{ Kabupaten } \\
\hline 1 & Tegalan / Ladang & 179,71 & 17,97 & Semplak & Bogor \\
\hline 2 & Tegalan / Ladang & 249,00 & 24,90 & Cibinong & Bogor \\
\hline 3 & Sawah Irigasi & 180,26 & 18,03 & Semplak & Bogor \\
\hline 4 & Tegalan / Ladang & 52,09 & 5,21 & Bojonggede & Bogor \\
\hline 5 & Tegalan / Ladang & 61,90 & 6,19 & Bojonggede & Bogor \\
\hline 6 & Tegalan / Ladang & 2258,56 & 225,86 & Bojonggede & Bogor \\
\hline 7 & Tegalan / Ladang & 2258,56 & 225,86 & Sawangan & Bogor \\
\hline
\end{tabular}




\begin{tabular}{|l|l|c|c|l|l|}
\hline No & \multicolumn{1}{|c|}{ Land Use } & $\begin{array}{c}\text { Luas Land Use } \\
(\mathbf{H a})\end{array}$ & $\begin{array}{c}\text { Luas Potensi Situ } \\
(\mathbf{H a})\end{array}$ & Kecamatan & \multicolumn{1}{|c|}{ Kabupaten } \\
\hline 8 & $\begin{array}{l}\text { Rumput/ } \\
\text { Tanah kosong }\end{array}$ & 47,48 & 4,75 & Sukmajaya & Bogor \\
\hline 9 & Tegalan / Ladang & 2258,56 & 225,86 & Sawangan & Bogor \\
\hline 10 & Tegalan / Ladang & 59,55 & 5,95 & Sukmajaya & Bogor \\
\hline 11 & Tegalan / Ladang & 2258,56 & 225,86 & Sawangan & Bogor \\
\hline 12 & Tegalan / Ladang & 87,90 & 8,79 & Sukmajaya & Bogor \\
\hline 13 & Tegalan / Ladang & 116,27 & 11,63 & Beji & Bogor \\
\hline 14 & Rumput/Tanah kosong & 113,81 & 11,38 & Ciracas & Jakarta Timur \\
\hline 15 & Rumput/Tanah kosong & 9,29 & 0,93 & Jaga Karsa & Jakarta Selatan \\
\hline 16 & Rumput/Tanah kosong & 140,37 & 14,04 & Cipayung & Jakarta Timur \\
\hline 17 & Rumput/Tanah kosong & 34,85 & 3,49 & Pondokgede & Bekasi \\
\hline 18 & Rumput/Tanah kosong & 60,31 & 6,03 & Lima & Bogor \\
\hline 19 & Rumput/Tanah kosong & 41,55 & 4,15 & Lima & Bogor \\
\hline 20 & Rumput/Tanah kosong & 232,09 & 23,21 & Pamulang & Tangerang \\
\hline 21 & Rumput/Tanah kosong & 232,09 & 23,21 & Pamulang & Tangerang \\
\hline 22 & Sawah Irigasi & 9,92 & 0,99 & Jaga Karsa & Jakarta Selatan \\
\hline 23 & Tegalan / Ladang & 46,55 & 4,66 & Jaga Karsa & Jakarta Selatan \\
\hline 24 & Tegalan / Ladang & 31,22 & 3,12 & Jaga Karsa & Jakarta Selatan \\
\hline 25 & Rumput/Tanah kosong & 32,78 & 3,28 & Lima & Bogor \\
\hline 26 & Rumput/Tanah kosong & 40,24 & 4,02 & Cilandak & Jakarta Selatan \\
\hline 27 & Rumput/Tanah kosong & 129,82 & 12,98 & Ciputat & Tangerang \\
\hline Jumlah & & 1122.35 & & \\
\hline & & & & \\
\hline
\end{tabular}

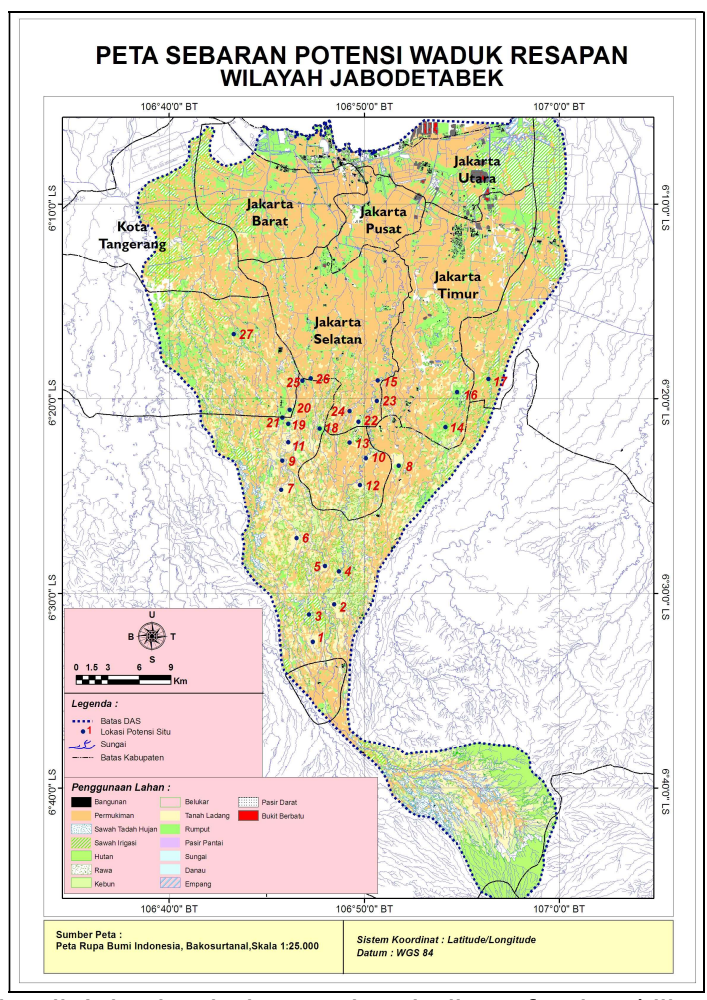

Gambar 4: Potensi situ-situ di Jabodetabek yang layak dimanfaatkan/dikembangkan sebagai waduk resapan 


\section{KESIMPULAN}

a. Situ-situ yang layak untuk dikembangkan sebagai waduk resapan yang masuk dalam DAS DKI Jakarta: Bekang/Gedong, Cikaret, Cilangkap, Cilodong, Citatah/Ciriung, Rektorat UI, Ekonomi UI, Politeknik UI, Salam UI, Asrama UI, Rawa Baru, RRI, Bojongsari/Sawangan, Gintung, Kemuning, Pamulang/Kedaung/Sasak, Pondok Benda/Kompeni/Ciledug, Tonjong dan Rawa Dongkal. Sementara situ-situ yang layak tetapi diluar DAS yang masuk ke DKI Jakarta sebanyak 6 (enam), yaitu : Cigago/Kemang, Cilala/Jampang, Iwul, Lebak Wangi, Malang Nengah, dan Gunung Putri.

b. Total luas lahan yang layak untuk pengembangan waduk resapan adalah 27 lokasi dengan luas 1122.35 ha. Hasil identifikasi lahan-lahan tersebut hanya mempertimbangkan keberadaan lahan tersebut di atas peta, aspek pemilikan lahan dari lahan-lahan kosong yang potensi untuk dikembangkan sebagai lokasi waduk resapan tidak mempertimbangkan aspek pemilikan lahan, selain itu data mengenai pemilihan lahan (persil) cukup sulit untuk diperoleh.

c. Persyaratan pembangunan waduk resapan dapat dibagi persyaratan teknis (rencana lokasi, luas dan pemilikan lahan, geologi teknik, sumber air dan prasarana bangunan air) dan non teknis teknis (legalitas, pengelolaan / O-P, peran masyarakat penerima manfaat/sekitar situ).

d. Desain waduk resapan yang dapat dikembangkan untuk situ-situ adalah : waduk resapan sederhana, waduk resapan sederhana satu kolam resapan akuifer (WR semi teknis) serta waduk resapan dengan kolam resapan akuifer dangkal / bebas dan kolam resapan akuifer dalam/tertekan (WR teknis).

\section{DAFTAR PUSTAKA}

1. Alikodra H.S, 1998, Perencanaan Pengelolaan Situ Di Wilayah Jabotabek Ditinjau Dari Aspek Perlindungan Dan Konservasi Sumberdaya Alam, Workshop Pengelolaan Situ-situ Di Wilayah Jabotabek.

2. Arif. B, 1998, Peranan Sektor Pengairan Dalam Pengelolaan Situ-situ Di Wilayah Jabotabek, Workshop Pengelolaan Situ-situ Di Wilayah Jabotabek.
3. Boyd, C.e. 1988. Water Quality in Warmwater Fish Pond. Fourth Printing. Auburn University Agricultural Experiment station. Alabama. USA.

4. Davies,J., G.Claridge dan Ch.Endah Nirarita.1995. Manfaat Lahan Basah. Asian Wetland Bureau dan Dit.Jen. Perlindungan Hutan dan Pelestarian Alam. Bogor, Indonesia. hal.1-20.

5. Davis, M.L. and D.A. Cornwell. 1991. Introduction to Environmental Engineering. Second Edition. McGraw-Hill, Inc. New York.

6. Dugan, P., 1993. Wetlands in Danger. Mitchell Breazley dan IUCN The World Conservation Union. London.

7. Effendi, H. 2003. Telaah Kualitas Air. Bagi Pengelolaan Sumber Daya dan Lingkungan Perairan. Penerbit Kanisius. Jakarta.

8. Gunawan E, 1998, Kebijaksanaan Pengelolaan Situ - situ Di Wilayah Jabotabek, Workshop Pengelolaan Situ-situ Di Wilayah Jabotabek.

9. Khiatuddin, M., 2003. Melestarikan Sumber Daya Air Dengan Teknologi Rawa Buatan. Gadjah Mada University Press. Yogyakarta.

10. Komite Nasional Pengelolaan Ekosistem Lahan Basah. 2005. Strategi Nasional dan Rencana Aksi Pengelolaan Lahan Basah Indonesia Jakarta. Kementerian Lingkungan Hidup. Jakarta.

11.Legowo, S., 2008, Pengembangan Master Plan Situ Sebagai Waduk Resapan, Bahan Presentasi pada Forum Group Discussion Permasalahan, Penanganan dan Sistem Peringatan Dini Banjir di DKI Jakarta, tidak diterbitkan

12. Maltby, E., 1991. Wetlands and Their Values. Dalam Finlayson dan Moser (eds.). 1991.

13. McNeely, R.N, Nelmanis, V.P., and Dwyer, L. 1979. Water Quality Source Book. A Guide to Water Quality Parameter. Inland Waters Directorate, Water Quality Branch. Ottawa. Canada.Mitsch, W.J., dan Gosselink, J.G. 2000. Wetlands, 3rd ed. John Wiley \& Sons. New York.

14. Moore, J,W. 1991. Inorganic Contaminant of Surface water. Springer Verlag. New York.

15.Nugroho, S.P., 2002. Evaluasi dan Analisis Curah Hujan Sebagai Faktor Penyebab Bencana Banji di Jakarta. Jurnal Sains dan Teknologi Modifikasi Cuaca. Vo.3 Nomor 2. Badan Pengkajian dan Penerapan Teknologi. Jakarta. 
16.Nugroho, S.P., A.I. Sitoresmi dan S.Y. Warsono. 2004. Prosiding Workshop Penataan Kawasan Pantai Utara Jakarta Dengan Pendekatan Pembangunan Berkelanjutan. Kementerian Negara Ristek. Jakarta.

17.PU, 2004, Detail Desain Situ-situ dan Waduk Resapan di kabupaten Bogor dan Depok

18.Rao, C.S. 1992. Environmental Pollution Control Engineering. Wiley Eastern Limited. New Delhi.

19.Ristek, 2004, Kajian Pengembangan Teknologi Waduk Resapan untuk Mengendalikan Banjir dan Kekeringan, Workshop Peranan Waduk Resapan dalam Mengatasi Banjir dan Kekeringan

20.Suryadiputra I.N.N., 1998, Penelitian Situ-situ Di Wilayah Jabotabek, Workshop Pengelolaan Situ-situ Di Wilayah Jabotabek. 